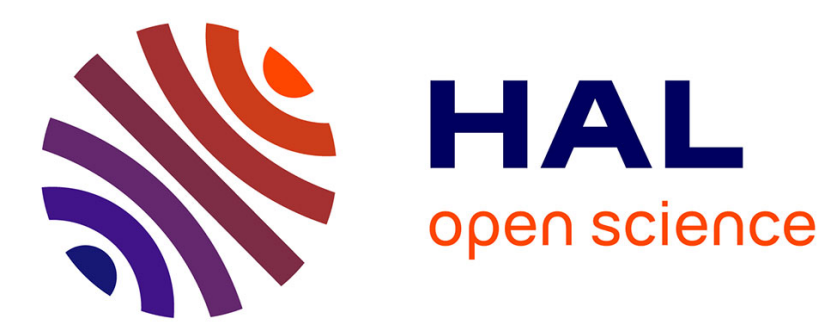

\title{
Recent advances in EEG-based neuroergonomics for Human-Computer Interaction
}

\author{
Jérémy Frey, Martin Hachet, Fabien Lotte
}

\section{To cite this version:}

Jérémy Frey, Martin Hachet, Fabien Lotte. Recent advances in EEG-based neuroergonomics for Human-Computer Interaction. 1st International Neuroergonomics conference, Oct 2016, Paris, France. hal-01394255

\section{HAL Id: hal-01394255 \\ https://inria.hal.science/hal-01394255}

Submitted on 9 Nov 2016

HAL is a multi-disciplinary open access archive for the deposit and dissemination of scientific research documents, whether they are published or not. The documents may come from teaching and research institutions in France or abroad, or from public or private research centers.
L'archive ouverte pluridisciplinaire HAL, est destinée au dépôt et à la diffusion de documents scientifiques de niveau recherche, publiés ou non, émanant des établissements d'enseignement et de recherche français ou étrangers, des laboratoires publics ou privés. 


\title{
Recent advances in EEG-based neuroergonomics for Human-Computer Interaction
}

\author{
Jérémy Frey ${ }^{1,2}$, Martin Hachet ${ }^{2}$, Fabien Lotte $^{2}$ \\ 1-University of Bordeaux, 2-Inria Bordeaux Sud-Ouest / LaBRI
}

Human-Computer Interfaces $(\mathrm{HCl})$ are increasingly ubiquitous in multiple applications including industrial design, education, art or entertainment. As such, $\mathrm{HCl}$ could be used by very different users, with very different skills and needs. This thus requires user-centered design approaches and appropriate evaluation methods to maximize User eXperience (UX). Existing evaluation methods include behavioral studies, testbeds, questionnaires and inquiries, among others. While useful, such methods suffer from several limitations as they can be either ambiguous, lack realtime recordings, or disrupt the interaction. Neuroergonomics can be an adequate tool to complement traditional evaluation methods. Notably, Electroencephalography (EEG)-based evaluation of UX has the potential to address the limitations above, by providing objective, realtime and non-disruptive metrics of the ergonomics quality of a given $\mathrm{HCl}$ (Frey 2014). In this abstract, we present an overview of our recent works in that direction. In particular, we show how we can process EEG signals in order to derive metrics characterizing 1) how the user perceive the $\mathrm{HCl}$ display ( $\mathrm{HCl}$ output) and 2) how the user interacts with the $\mathrm{HCl}(\mathrm{HCl}$ input).

First, at the output level, we conducted some experiments to study the visual comfort experienced by users of stereoscopic displays (e.g., 3D TV). We showed them several objects presented at different stereoscopic depths in front or behind the screen while recording their EEG signals. Some of these depths were voluntarily uncomfortable (either too close or too far from the eyes). By analyzing Event Related Potentials (ERP) following a stereoscopic object appearance using advanced EEG signal processing techniques, we showed we could discriminate, in a single trial (i.e., in 1s of signal), ERP corresponding to comfortable displays versus ERP corresponding to uncomfortable ones (Frey 2016a).

Second, we asked our users to perform different cognitive tasks involving different levels of cognitive workload (i.e., mental efforts), while recording their EEG signals. Here as well, by using signal processing and suitable machine learning, we could discriminate low mental workload from high mental workload in short windows (2s of signal) of EEG (Mühl 2014). By refining these algorithms we showed we could then discriminate mental efforts in complex interaction tasks, notably during 3D object manipulation tasks (Wobrock 2015), as well as during navigation tasks In a video game (Frey 2016b). We also showed we could use such methods to compare the mental workload induced by different interaction devices or techniques.

Overall, these recent results suggest that EEG can be used as an objective and complementary evaluation technique to characterize and assess different $\mathrm{HCl}$. This thus opens the door to a new generation of $\mathrm{HCl}$, designed by exploiting EEG-based neuroergonomics.

\section{References:}

Frey, J., Appriou, A., Lotte, F., \& Hachet, M. (2016a). Classifying EEG Signals during

Stereoscopic Visualization to Estimate Visual Comfort. Computational Intelligence \&

Neuroscience.

Frey, J., Daniel, M., Hachet, M., Castet, J., \& Lotte, F. (2016b). A framework for electroencephalography-based evaluation of user experience. Proc. $\mathrm{CHI}$

Frey, J., Mühl, C., Lotte, F., \& Hachet, M. (2014). Review of the use of electroencephalography as an evaluation method for human-computer interaction. Proc. PhyCS.

Mühl, C., Jeunet, C., \& Lotte, F. (2014). EEG-based Workload Estimation Across Affective Contexts. Frontiers in Neuroscience, 8, 114

Wobrock, D., Frey, J., Graef, D., Riviére, J.-B. de la, Castet, J., \& Lotte, F. (2015). Continuous Mental Effort Evaluation during 3D Object Manipulation Tasks based on Brain and Physiological Signals. Proc. Interact 